\title{
Diseño de la cáscara de ladrillo en la reconstrucción de la bóveda de la capilla del Palacio de Dresde: un intento de recuperación del olvidado arte de construir bóvedas tardogóticas
}

\author{
Designing a Masonry Shell in the Reconstructed Vault of \\ the Palace Chapel at Dresden - an Attempt to Recover \\ the Forgotten Art of Late Gothic Vault Construction
}

D. Wendland $^{(*)}$, M. J. Ventas-Sierra ${ }^{(*)}$

\section{RESUMEN}

En la capilla del Palacio de Dresde se está reconstruyendo una bóveda de nervios de doble curvatura conforme a la original del siglo XVI. Aunque bóvedas de complejidad similar todavía perviven, constituyendo una de las tipologías arquitectónicas más asombrosas y emocionantes del tardogótico, no se han construido bóvedas de este tipo desde hace 450 años. La cáscara estructural de ladrillo sin armadura ha debido adaptarse al complejo sistema de nervios. Su diseño, búsqueda de la forma y desarrollo han sido llevados a cabo por un equipo interdisciplinario, teniendo en cuenta: el aspecto visual, las condiciones estructurales para ser una superficie de equilibrio, la moldeabilidad de la fábrica de ladrillo, los detalles de los encuentros entre nervios y cáscara, y las posibilidades de construir la cáscara "a mano libre", sin encofrado. El objetivo pudo ser alcanzado mediante el empleo de CAD, modelación numérica, un modelo físico de simulación y un prototipo a escala 1:1.

970-6

Palabras clave: Tardogótico; reconstrucción; bóveda; nervios de doble curvatura; cáscara; técnica de construcción histórica; forma libre; modelación CAD; modelo físico; Dresde; Sajonia.

\section{SUMMARY}

In the chapel of the Dresden Castle, a vaulted ceiling with double-curved ribs is currently being reconstructed according to the original from the 16th century. Similar highly complex rib vaults from this period still survive, and are some of the most exciting architectural features of the late Gothic, but no vault of this type has been built for 450 years. The load-bearing masonry shell in unreinforced brick masonry is designed upon the complex system of curvilinear ribs. Design, form-finding and development have been carried out by an interdisciplinary team, taking in account the following: visual appearance, the structural demand according to the equilibrium surface, the moldeability of masonry, the detailing of the connection between ribs and the shell, as well as the possibility of building the shell free-handed, i.e. without formwork. This aim could be achieved by combining CAD and numerical modeling, physical simulation model and a full scale prototype.

Keywords: Late Gothic; reconstruction; vault; double-curved ribs; shell structure; historical building technique; free form design; CAD modeling; physical modeling; Dresden; Saxony.

(*) REGothic VaultDesign (ERC) - Technische Universität Dresden, Dresde (Alemania). 


\section{INTRODUCCIÓN}

En la reconstrucción de la bóveda de la capilla del Palacio de Dresde, la manera de abordar el proyecto no ha sido buscando obtener una mera réplica de la bóveda desaparecida, sino persiguiendo una solución arquitectónica que adquiriese su autenticidad al aplicar los principios y métodos proyectivos del tardogótico, al emplear los materiales originales -nervios de piedra natural, albañilería de ladrillo y mortero de cal-y al aplicar la técnica histórica de construcción de bóvedas "a mano libre" (1) (2) (3) (4). Su estructura es la de una cáscara de ladrillo con nervios de piedra en el intradós y sin armadura. No obstante, la estructura autoportante debe satisfacer todas las exigencias de un edificio de nueva construcción, por lo que el diseño estructural tiene que garantizar el cumplimiento de la normativa vigente y los estándares de calidad y seguridad.

Las dimensiones totales de la bóveda son $27,5 \mathrm{~m}$ de longitud por 12,6 $\mathrm{m}$ de anchura, que incluyen nave central y dos naves laterales. La nave central tiene una luz de 8,00 m. El espesor de la cáscara es de $14 \mathrm{~cm}$, excepto a lo largo de los nervios adicionales del extradós y en las zonas sobre los apoyos, donde tiene $28 \mathrm{~cm}$ de espesor.

\subsection{La Capilla del Palacio de Dresde, 1550-1737}

El "Residenzschloss" de Dresde aparece mencionado por primera vez en documentos del siglo XIII, pero fue en el siglo XVI cuando sufrió una ampliación que le convirtió en uno de los grandes palacios renacentistas de los príncipes electores sajones (5). La nueva capilla del palacio, localizada en el ala norte (Figura 1), fue una de las primeras iglesias construidas para la confesión protestante y llegó a ser muy conocida, especialmente por la música de su orquesta, en su época dirigida por el famoso compositor Heinrich Schütz. Dos siglos después, en 1737, la capilla fue abandonada al convertirse los príncipes sajones al catolicismo y erigir la nueva iglesia de la corte (Hofkirche). Como consecuencia, el edificio fue transformado y la bóveda de la capilla demolida.

Tras la destrucción del palacio en el bombardeo de Dresde durante la Segunda Guerra Mundial, la única medida que se tomó fue la de preservar los fragmentos de muro perimetral que habían quedado en pie. En obras de consolidación realizadas en la década de los 80 se reforzaron los pilares y algunos tramos de muro fueron lamentablemente desmontados y reconstruidos en

\section{INTRODUCTION}

In the current reconstruction of the vaulted ceiling in the former chapel of the Dresden Castle (Dresden, Germany), the approach to the design has not been to merely attempt a replica of the destroyed historical vault, but rather to create an architectural solution that achieves authenticity by resuming the late Gothic design principles, using the original materials such as stone ribs and brick masonry, and implementing the historical construction process of freehanded vault construction (1) (2) (3) (4). The structure is a shell in unreinforced brick masonry, with ribs of natural stone on the intrados. Nevertheless, the self-supporting structure has to meet all requirement of a new building, and so the structural design fulfils current building codes and safety and quality standards.

The dimensions of the vaulted ceiling are $27.50 \mathrm{~m}$ in total length and $12.60 \mathrm{~m}$ in width, including the central and two lateral naves. The free span of the central nave is $8.00 \mathrm{~m}$. The shell thickness is $14 \mathrm{~cm}$ in most parts, except for additional masonry ribs on the extrados and the portions directly above the springing, where it is $28 \mathrm{~cm}$.

\subsection{The Chapel in the Dresden Castle, 1550-1737}

The palace of Dresden was first mentioned in the $13^{\text {th }}$ century, but underwent major amplification in the $16^{\text {th }}$ century to become one of the great Renaissance palaces of the Saxon Prince Electors (5). The new chapel of the renovated palace, located in the north wing (Figure 1), was one of the first churches built for the Protestant confession and became prominent especially for the music of its orchestra which was conducted by the famous composer Heinrich Schütz. However, little more than two centuries later, in 1737 the chapel was abandoned when the Saxon princes became Catholic and the new court church (Hofkirche) was built. Consequently the building was transformed and the vaulted ceiling demolished.

After the destruction of the palace in the bombing of Dresden in World War II, the only immediate interventions consisted in conserving the more stable parts of the perimeter walls that were still standing. In the consolidation works, which were carried out in the 1980s, the pillars and some portions of the walls were reinforced with concrete, and unfortunately most of the original walls were demolished and reconstructed in concrete. Further, 
hormigón, recuperando la volumetría del edificio. Los trabajos actuales están dirigidos a reconstruir la desaparecida bóveda de la antigua capilla y a rehabilitar los salones situados en el piso superior.

El cerramiento abovedado original era con seguridad una bóveda gótica con nervios de doble curvatura. Construida alrededor de 1550, fue una de las últimas de este tipo en Sajonia. Toda la información existente sobre la arquitectura de la capilla consiste en algunas fotografías de una maqueta original del proyecto, hoy destruida, en las que se pueden ver los pilares y la galería. Pero el único documento que muestra la bóveda es una perspectiva del interior de la capilla de 1676 (Figura 2) (5) (6). Los restos arqueológicos conservados consisten tan sólo en algunos fragmentos de nervio de la bóveda original, en los que se puede ver el perfi que tenían, así como su doble curvatura, confirmando lo que podemos ver en el grabado. Además, en algunos tramos de muro original se podían ver trazas de la bóveda.

A pesar de la escasa documentación disponible, es posible hacerse una idea bastante clara sobre el aspecto que debió de tener la capilla observando construcciones comparables (5). Por ejemplo, la capilla del palacio de Berlín tenía una bóveda muy similar y aunque fue demolida en 1950, se conservan numerosas fotografías que la documentan. Además, en Bohemia y Sajonia se pueden encontrar algunos ejemplos excelentes de bóvedas tardogóticas con nervios de doble curvatura, que pueden proporcionar evidencia del aspecto figurativo, construcción, detalles y materiales, así como de los conceptos geométricos usados por los maestros constructores góticos.

\subsection{Estudios sobre bóvedas tardogóticas con nervios de doble curvatura}

Durante los siglos XIV y XV la fascinación que despertaba la construcción de bóvedas condujo a soluciones cada vez más complejas (7). Fue en este contexto que se inventaron las bóvedas cuyos nervios, además de ser curvos en el plano vertical, también lo eran en planta, presentando por tan- the external cubature of the building was recovered. The current construction works aim to reconstruct the vaulted ceiling of the former chapel and rehabilitate the parade rooms on the second floor.

The original vaulted ceiling was surely a late Gothic rib vault with curvilinear stone ribs - built around 1550 as one of the last of its kind in Saxony. Information about the architecture of the chapel can be obtained from the photographs of an original model of the project, today destroyed, showing the pillars and the gallery. But the only document that actually shows the vault is a perspective drawing of the internal of the chapel (Figure 2) (5) (6). The most important archaeological remains consist of several fragments of the stone ribs of the original vault; they give evidence of the rib profile as well as of the double curvature, thus confirming what can be seen in the drawing. Also, the few remaining original wall portions conserve some traces of the vault.

In spite of the scarce documentation, a rather clear picture about how the vault of the chapel must have looked can be gained from observations of comparable constructions (5). For instance, the chapel in the Berlin Palace had a vaulted ceiling that was closely related to that in Dresden, and which, although demolished in 1950, is well documented by photographs. Beyond that, many late Gothic vaults with curvilinear ribs, among those some very fine examples in Bohemia and Saxony, can give evidence of the appearance, construction, detailing and materials, as well as on the geometrical concepts used by the late Gothic master builders.

\subsection{Late Gothic vaults with curvilinear ribs}

During the $14^{\text {th }}$ and $15^{\text {th }}$ centuries, the fascination with the challenge of creating vaulted ceilings lead to ever more complex solutions in late Gothic architecture (7). In this context, rib vaults were invented in which the ribs, in addition to their curvature in elevation, are curved also in
1. Ala norte del Palacio de Dresde (siglo XVI), donde se encuentra la capilla. (Fotografía de los autores).

1. North wing of Dresden Castle (16th century), where the chapel is located (photograph by the authors).

2. Grabado del interior de la capilla durante un concierto (David Conrad, 1676). La bóveda con nervios de doble curvatura es claramente visible. (Staatsarchiv Dresden).

2. Etching showing the interior of the original chapel during a concert (David Conrad, 1676). The vaulted ceiling with double curved ribs is clearly visible (Staatsarchiv Dresden).
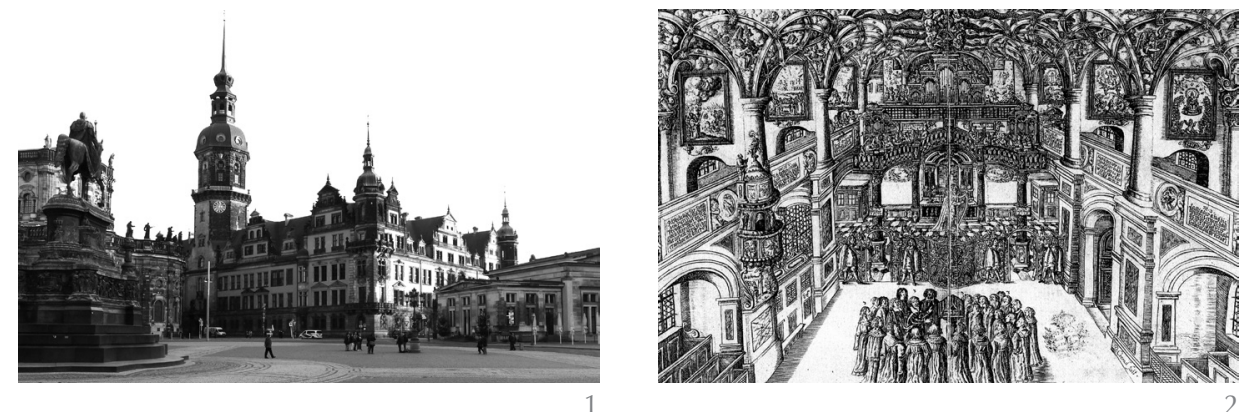
3. Bóveda de la sala de Vladislav del Palacio Real de Praga. Fue la primera bóveda con nervios que se curvan también en planta a escala monumental: su luz es de $16 \mathrm{~m}$. (Fotografía de los autores).

3. Vault of the Vladislav Hall in the royal palace at Prague. This was the first vault in monumental size with ribs curved also in the plan; the span is $16 \mathrm{~m}$ (photograph by the authors). to una doble curvatura. La primera bóveda monumental de este tipo fue la de la sala de Vladislav del Palacio Real de Praga (Figura 3), completada en 1502 por Benedikt Ried (7) (8). A continuación, una serie de bóvedas similares fueron construyéndose en Bohemia y Sajonia, como la de la iglesia de Kutna Hora (República Checa), también proyecto de Ried, las bóvedas de la iglesia de Annaberg y de la sala de armas del Albrechtsburg de Meissen, ambas construidas por Jakob Haylmann, y una capilla de Viena atribuida a Anton Pilgram. Ejemplos posteriores fueron las capillas de los palacios de Berlín y Dresde.

Es obvio que el tipo de curvas de estas complejas estructuras espaciales es determinante para el impacto visual que tendrá en el observador. Como es usual en las bóvedas góticas, el concepto geométrico total no se basa en superficies predeterminadas geométricamente, de cuyas intersecciónes resultan las lineas de los nervios (como en la práctica barroca y de acuerdo con las reglas de la estereotomía clásica), sino que, por el contrario, se desarrolla partiendo de las curvas de los arcos y nervios, definidas en términos geométricos elementales (9) (10) (11) (12). Los arcos y nervios, por tanto, son curvas autónomas (normalmente segmentos de círculo) que siguen sus propias reglas y constituyen la característica primaria, mientras que la superficie de la bóveda tiene que ajustarse a estas curvas.

Este principio es bien conocido para el caso de bóvedas con nervios y aristas planas. Las fuentes escritas, en particular dibujos y algún tratado sobre el proyecto tardogótico, proporcionan indicaciones sobre cómo la generación de las curvas de los nervios se traducía en instrucciones para la producción y ensamblaje de las piezas plan, thus having double curvature. The first monumental ceiling of this type was that of the huge Vladislav Hall (Figure 3) in the royal palace at Prague, completed in 1502 by Benedikt Ried (7) (8). Several similar vaults were subsequently built in Bohemia and Saxony, such as in St. Barbara's Church in Kutná Hora (Czech Republic) also designed by Ried, and in St. Anne's Church at Annaberg as well as the "Hall of Arms" in the Albrechtsburg at Meissen (Germany), both by Jakob Haylmann, and a chapel in Vienna which is attributed to Anton Pilgram. Later examples of this series were the vaults in the chapels of the Berlin and Dresden Castles.

It is obvious that the character of the curves in these complex spatial structures determines their visual impact. As it is generally case with Gothic vaults, the geometric concept is not based on geometrically determined surfaces and their intersection curves (as in the baroque design schemes and the concepts of classical stereotomy), but, on the contrary, is developed starting from the curves of the arches, which are defined a priori by elementary geometric terms (9) (10) (11) (12). The arches and ribs, therefore, describe autonomous curves (usually circle segments) and constitute the primary feature, while the vault surface has to adjust to these curves.

This principle is well-known for vaults with plane ribs and groins. The sources, in particular collections of drawings and the few treatises related to the late Gothic design practice, give some indication of how the design for the curves of the arches could be transferred to the instructions for the preparation and assembly of the stone members, a task which was undoubtedly greatly simplified by this particular approach to the geometric concept (11) (13).

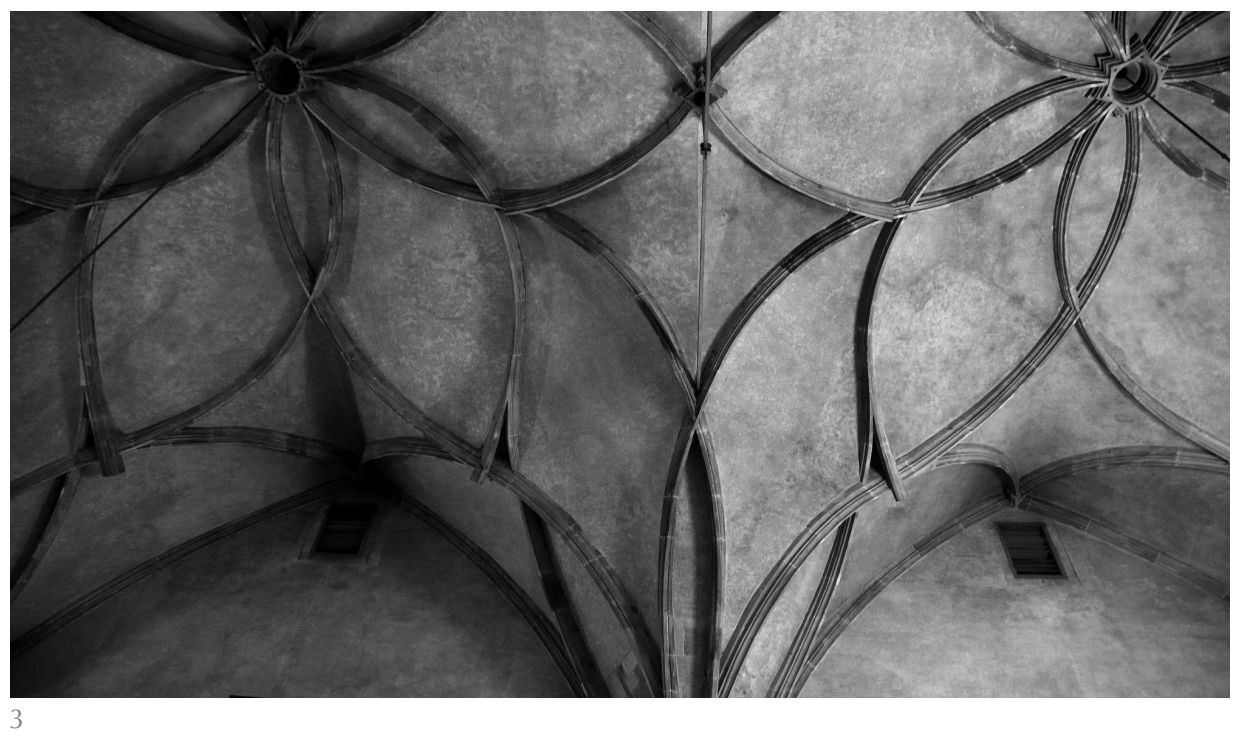


de piedra, y estas indicaciones han podido ser contrastadas e interpretadas en base a levantamientos (11) (13).

Sin embargo, cuando se trata de nervios de doble curvatura, las fuentes ofrecen una muy escasa información, así que para entender cómo se generan y describen esas curvas sólo podemos recurrir a análisis de edificios existentes. Partiendo de mediciones tridimensionales y análisis podemos formular hipótesis sobre el proyecto geométrico e intentar reconstruir qué especificaciones fueron definidas y transmitidas para la realización.

Para poder reconstruir una bóveda de este tipo en la práctica, era muy importante basarse en esta investigación en curso: por un lado, algunas afirmaciones en la literatura sobre el tema se demostraron, cuando menos, problemáticas (12) (14), y por otro lado era crucial para la autenticidad del proyecto que las curvas de los nervios fueran proyectadas de acuerdo a como se hacía en las bóvedas originales tardogóticas.

En todos los casos estudiados hasta el momento, las curvas de los nervios describen círculos o segmentos de círculo en su proyección en planta. Por tanto, lo que necesitaba ser aclarado era cómo se fija el desarrollo vertical de la curva. Para el caso de la sala de Vladislav en Praga, la definición tridimensional de las curvas había sido aclarada por Jan Muk (8). Según este estudio, las curvas pueden describirse como segmentos de círculo que se curvan según la curva en planta (Figura 4). En términos geométricos, explica Muk, esta curva se puede definir como una espiral. Este resultado encaja perfectamente con la manera de proyectar bóvedas tardogóticas, con curvas que nunca se generan por proyección, sino que siempre se opera con longitudes reales.

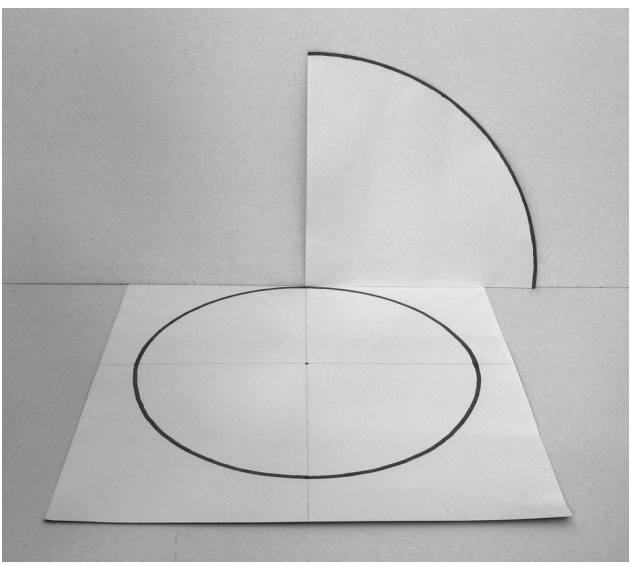

However, the information given by these sources regarding the design of vaults with double-curved ribs is very scarce -the procedure for the generation of the curves is not described in any of the sources related to the late Gothic design practice at all, including the later sources that refer to its tradition. Therefore, the research carried out on how these curves were defined and described in instructions for the execution, has to start from studies on the built objects. On the basis of three-dimensional measurements and geometric analyses carried out on existing vaults, hypotheses about the geometrical concept have been developed as well as on the way design specifications could have been formulated and transmitted for their realization.

For the task of reconstructing a vault of this kind, it was very important to recur to these ongoing studies for two reasons: First, some assertions on this subject in the existing research literature turn out to be, at the least, problematic (12) (14), and second, if the reconstructed vault is to be authentic it is crucial to develop a geometric concept in accordance to the late Gothic design practice.

In all of the cases studied so far, the curves of the ribs in the plan describe circles or circle segments. Therefore, it had to be ascertained how the vertical development of the curves could have been determined. For the case of Benedikt Ried's vault in the Vladislav Hall in Prague mentioned above (Figure 3), this was clarified in 1990 by Jan Muk (8). According to his study based on surveys, the three-dimensional curves of the ribs can be described as circle segments which are "enrolled" according to the curvature in the plan (Figure 4). In geometric terms, as Muk points out, such a curve can be characterized as a spiral, where the vertical development is defined by a circle segment. Such a geometric definition is completely in accordance with
4. Visualización de la manera de generar las curvas de los nervios: su desarrollo en la tercera dimensión se determina curvando un segmento de círculo situado en un plano vertical, sobre el círculo en planta. (Fotografía de los autores).

4. Visualization of the geometric construction of the double curved ribs: their development in the third dimension is determined bending a circle segment in the vertical plane according to the circle in the plan (photographs by the authors). 
5. Bóveda de la Sala de Armas del Albrechtsburg de Meissen. (Fotografía de los autores).

5. The vault in the "Hall of Arms" in the Albrechtsburg at Meissen (photograph by the authors).

6. Análisis geométrico de los nervios según los datos obtenidos en el levantamiento.

6. Geometric analysis of the nerves in the "Hall of Arms" based on the survey data.
Hemos podido confirmar estas conclusiones en dos estudios-caso, en los que se buscaba además una metodología apropiada para poder interpretar y discutir de manera transparente los datos obtenidos (15). De particular interés resulta la bóveda de la "Sala de Armas" del Albrechtsburg de Meissen (1520) (Figura 5). Esta bóveda combina nervios planos con tres tipos de nervios tridimensionales. De acuerdo con el análisis geométrico, la curva en planta de uno de los tipos de arco tridimensional se puede describir como compuesta por dos segmentos de círculo con diferentes radios y continuidad tangente (Figura 6). La curva vertical que se arrolla sobre ella está tambien compuesta por dos segmentos de círculo, cuyo punto de tangencia se corresponde con el de la planta. Los otros dos tipos de nervios tridimensionales también son segmentos de círculo en planta y en desarrollo. Así, todos los nervios de doble curvatura en esta bóveda han sido definidos según este concepto de espiral.

Queda abierta la cuestión de cómo podrían haberse formulado las instrucciones para la producción de cada una de las piezas que forman el nervio, de acuerdo con dichas curvas. No parece razonable asumir que se habría hecho dibujando curvas en las seis superficies del bloque de piedra, porque en las superficies de los flancos estas curvas planas tendrían que haber sido proyecciones de la curva espacial de la espiral, y la pieza final habría que obtenerla de nuevo por proyección. Aparte de que un procedimiento tan propenso a error no llevaría a unos resultado de tan alta precisión como vemos en los nervios construidos, la objeción principal es que sería una contradicción absurda, tratándose de una curva que en principio no se genera por proyección. Pero en algunos tratados antiguos de estereotomía podemos encontrar un método alternativo para definir elementos pétreos complejos por medio de plantillas flexibles -"par panneaux" (10) - que sería factible y completamente coherente con la manera de proyectar las curvas. Podemos concluir what we know about the techniques for constructing curves used by the late Gothic architects, who never constructed curves by projection, but always operated with real lengths.

We were able to confirm this concept with two case-studies, in which we also developed a possible methodological approach to the interpretation of measuring data from objects with a complex shape, and of how to discuss the conclusions with the necessary transparency (15). Of particular relevance are the studies carried out on the vault of the "Hall of Arms" (1520) in the Albrechtsburg at Meissen (Figure 5). In this vault, plane diagonal ribs are combined with three groups of ribs with three-dimensional curves. According to the geometric analyses, the curve described by the long curvilinear ribs in the plan (i.e., its projection in the horizontal plane) can be characterized as an oval arch, composed of two circle segments with different radii and tangential continuity (Figure 6). The vertical development is also composed of two different circle segments, "enrolled" along, and divided according to, the curve in plan. The other two groups of curvilinear ribs describe circle segments both in the plan and the "enrolled" vertical surfaces they are inscribed. We can conclude that all the curves described by the curvilinear ribs are characterized as spirals.

After clarifying the curve generation in principle, the question remains how the instructions for making the single stone elements could be formulated in accordance. For this purpose, it doesn't seem reasonable to assume a procedure that consists in tracing curves on the six sides of the rectangular stone block, because this would mean initially generating plane projections of the spiral curve, and then producing the work-piece by re-projecting these projected curves again into the block in order to obtain the designed spatial curve. Apart from being prone to errors (which doesn't correlate

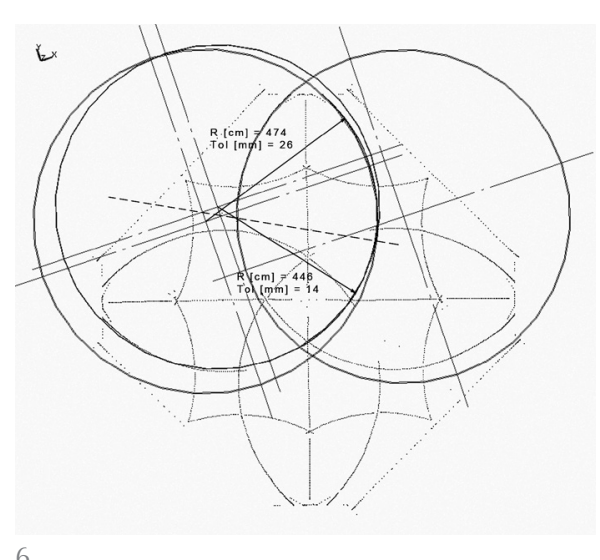


que para tallar los bloques de piedra se empleó un procedimiento similar.

Una comprensión aún más aproximada podría obtenerse de un breve pasaje que encontramos en uno de los pocos tratados relativos a la construcción de bóvedas góticas existentes (Lorenz Lechler), donde se menciona una plantilla ("Führbrett") que se puede interpretar, de acuerdo con un dibujo del mismo manuscrito (16), como una tabla-guía curva que se usa en combinación con una plomada (Figuras 7,8). Con este instrumento es posible controlar a la vez la curvatura horizontal de la dovela a tallar y la traslación del perfil sin perder la verticalidad (Figura 9). Por todo esto, la caracterización del modelo de proyecto geométrico obtenido de los levantamientos se puede confirmar considerando esta posible solución para el problema de la transmisión de instrucciones para la fabricación de las piezas.
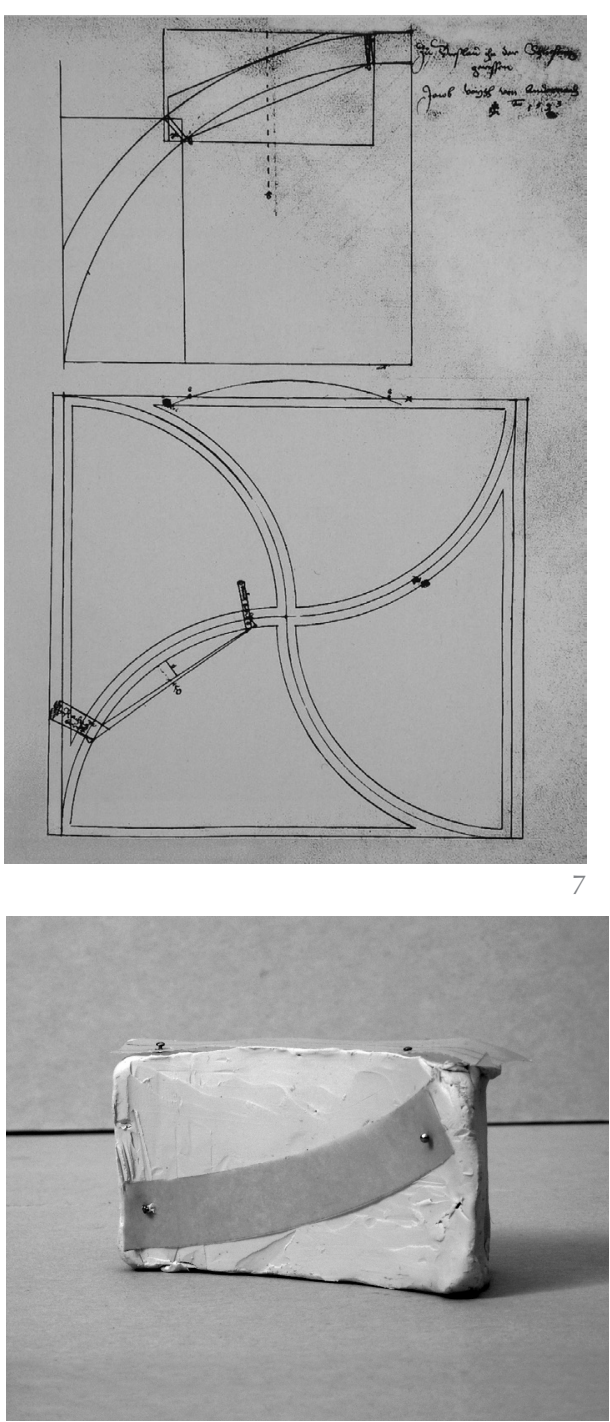

with the perfectly executed curves we can observe in the built objects), from the conceptual point of view, such a procedure would be in absurd contradiction to the curve generation as non-projected curve, as we pointed out. However, we can find alternative methods for defining the geometry of the work-piece in some of the earlier treatises on stereotomy, in particular some references to the use of flexible templates - "panneaux" (10)- which would be feasible and absolutely consistent with the way of defining the curves as described. Therefore, we may conclude that in cutting the stone members of these rib vaults, some similar procedure might have been applied.

We might gain further understanding from a short passage in one of the few existing treatises concerned with late Gothic vault construction (Lorenz Lechler), where a template is mentioned ("Führbrett"). This template, in combination with a drawing contained in the same manuscript (16) may be interpreted as some sort of curve ruler to be used in combination with a plumb line (Figures 7, 8). With this device it would be possible to control simultaneously the horizontal curve of the rib member to be carved and the translation of the profile, keeping it at all times vertical (Figure 9). We suggest a combined use of flexible templates, a curve ruler and a plumb line as a hypothesis of how the specifications for the single members could be derived in coherence with the concept we encounter in the surveys as well as with the known principles of late Gothic vault design.

\subsection{Curves and surfaces}

As we have seen, by principle, the geometric concept in Gothic vaults is based on the definition of the curves of the arches and ribs as autonomous curves which are predetermined with elementary geometric terms, and adapting the surface of the vault to these curves. As a consequence, the vault surface assumes a complex geometry, which,

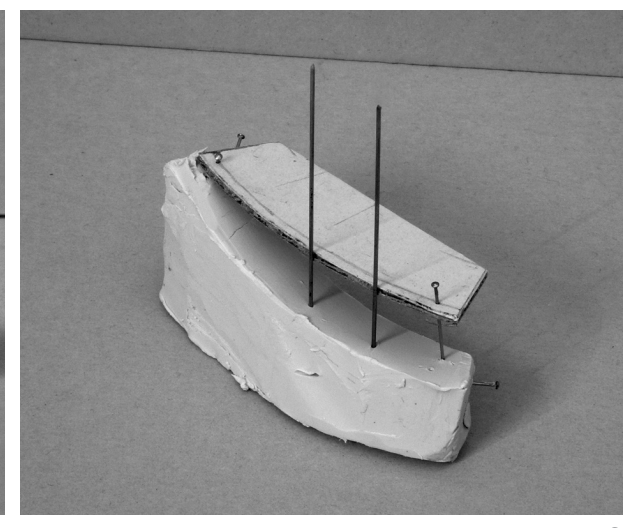

7. Dibujo de proyecto de una bóveda contenido en el manuscrito de Jakob Facht, 1593. (Colonia, Historisches Archiv Best.7020 Nr. 276).

7. Drawing of the geometric concept of a late vault contained in the manuscript by Jakob Facht 1593 (Cologne, Historisches Archiv Best. 7020 Nr. 276).

8. Estudio de la talla de las dovelas de doble curvatura simulando el uso de una plantilla flexible y de una guía curva en combinación con una plomada. (Fotografías de los autores).

8. Study on the possible procedure for defining and carving a single member of a rib with double curvature, simulating the use of a flexible template and of a curved ruler in combination with a plumb line (photographs by the authors).

9. Sala de Armas del Albrechtsburg de Meissen: se observa cómo la sección de los nervios mantiene la verticalidad. (Fotografía de los autores).

9. "Hall of Arms" in the Albrechtsburg at Meissen: the profile of the double curved ribs remains vertical along its course (photographs by the authors).

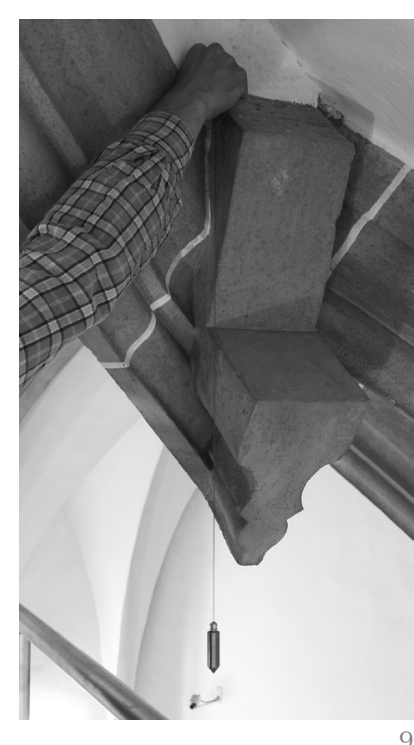


10. Detalle de la bóveda de la Sala de Armas del Albrechtsburg de Meissen: los nervios se cruzan a distintos niveles. (Fotografía de los autores).

10. Detail of the vault in the "Hall of Arms" in the Albrechtsburg at Meissen: the ribs intersect on different levels (photograph by the authors).

\subsection{Curvas y superficies}

Como hemos visto, el principio básico de diseño de las bóvedas tardogóticas partía de definir primero arcos y nervios como curvas autónomas de geometría elemental, y adaptar después la superficie de la bóveda a esas curvas. Ésta presenta por tanto una geometría compleja, algo que en la práctica no suponía un problema, ya que normalmente se construían en albañilería de ladrillo sin cimbrado total; para construir "a mano libre" no se necesitaba una descripción geométrica previa de la superficie. Así, las condiciones de contorno que determinarán la forma de la superficie de la bóveda son: el sistema de arcos, los requisitos debidos a la tipología constructiva "a mano libre", los límites de la viabilidad de construir superficies curvas con ladrillos y la figura de equilibrio de la cáscara, que tiene que estar contenida en su sección. Por todo esto, la forma de la cáscara se puede describir como una forma libre resultante de un proceso "orgánico" (17).

Pero cuando los nervios son de doble curvatura, el desarrollo de la superficie de la bóveda es más complicado, ya que la superficie no siempre puede adaptarse al sistema de curvas de los nervios y a veces tiene que separarse de su extradós. Esto es debido al hecho de que los nervios pueden desarrollarse a distintos niveles, superponiendose en lugar de interseccionándose (Figura 10), y a que la cáscara de albañilería es el elemento portante de estas bóvedas y debe ser estable por su forma. En concreto, la superficie debe discurrir de manera continua desde la cima hasta los arranques. Es obvio que los maestros constructores de los siglos XV y XVI sabían muy bien que la superficie de la bóveda no podía simplemente acomodarse sobre los extradoses de los nervios (15).

\section{EL DISEÑO DE LA BÓVEDA Y SU REALIZACIÓN}

\subsection{Concepto estructural}

Como ya hemos avanzado, los materiales empleados para la reconstrucción de la bóveda de la capilla han sido piedra arenisca para los nervios y ladrillos hechos a mano para la cáscara. Éstos fueron producidos a la manera tradicional para que tuviesen la porosidad requerida por la técnica a mano libre y pudiesen ser cortados in situ con una simple piqueta. De acuerdo con lo observado en ejemplos históricos, su formato $-28 \times 13,5 \times 6 \mathrm{~cm}$ - es ligeramente however, did not cause any difficulties in practice since the shell was usually built in brick masonry without formwork: for free-handed vaulting, it is not necessary to provide any geometric description of the surface in the design. All in all, the boundary conditions that determine the development of the vault surface are the system of arches, the requirements due to free-handed vaulting, the feasibility of curved surfaces in masonry, and the equilibrium figure of the shell (which has to result within the rather thick masonry surface). We can therefore characterize the shell surface as a free form resulting from a self-forming process (12) (17).

In the vaults with curvilinear ribs, the development of the vault surface becomes more complicated, as the shell cannot always adapt to the spatial system of curves constituted by the ribs and will therefore often detach from the ribs' extradoses. This is due to the fact that the rib system may develop in different layers, overlapping instead of intersecting (Figure 10), and also to the fact that the masonry shell is the load bearing feature of these vaults, working as a shell, and therefore must present a stable form. In particular, the surface flow from the summit to the springing must be continuous. Obviously, the master builders in the $15^{\text {th }}$ and $16^{\text {th }}$ century knew this very well - the vault surface in many cases cannot simply be molded upon the extradoses of the ribs (15).

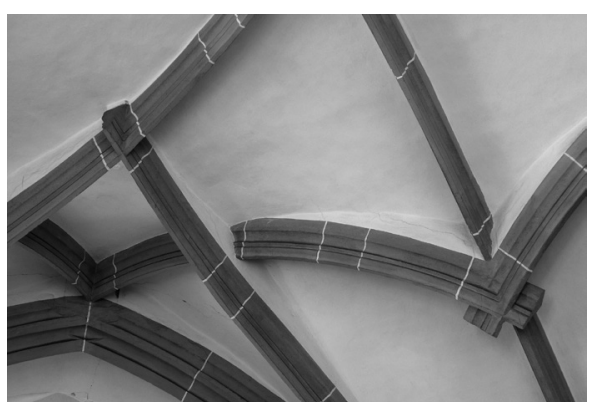

10

\section{THE DESIGN AND CONSTRUCTION OF THE VAULT}

\subsection{Structural concept}

As in the original, the materials we use in the reconstructed vault are sandstone for the ribs, and brick masonry for the shell. For the latter, handmade bricks are used, which were produced in the traditional manner so that they have the porosity necessary for the process of free-handed vaulting and so they can be cut to the right shape ad hoc with the brick axe. The format -28.0 $x 13.5 \times 6.0 \mathrm{~cm}$ - was chosen according to historical samples and is slightly larger 
más grande que el de los ladrillos normales actuales. El mortero es de cal tradicional con una preparación que comunmente se utizaba en bóvedas.

El principal elemento portante de estas bóvedas es la cáscara de albañilería, mientras que los nervios de piedra no tienen función estructural, ya que debido a su curvatura no pueden soportar esfuerzos normales. Las piezas que componen los nervios se conectan entre sí por medio de pernos metálicos en el sentido longitudinal de la pieza. De cada perno sale una pletina que sirve de conexión con la obra de albañilería, detalle que también podemos encontrar en ejemplos históricos, como es el caso de la bóveda de la sala de Vladislav (18).

En la cáscara los ladrillos están colocados a rosca. Si bien en las bóvedas tardogóticas de esta zona normalmente se observa un espesor correspondiente a la longitud de un ladrillo, para nuestro caso se optó por un espesor de sólo medio ladrillo para reducir el peso propio y por lo tanto el empuje. Otras posibles soluciones, como la bóveda tabicada, no se tomaron en consideración al no pertenecer al repertorio de técnicas tradicionales en Alemania.

\subsection{Metodología y búsqueda de la forma}

Ya que la bóveda tiene que trabajar como una cáscara, su forma es decisiva para el comportamiento estructural del conjunto, por tanto no puede simplemente desplegarse de nervio a nervio. Por otro lado, la manera de conectar la superficie con los nervios es determinante para la apariencia de la bóveda, por lo que por fuerza tiene que ser objeto de diseño arquitectónico. Además, debe ser posible obtener la curvatura de la superficie con las posibilidades y limitaciones de los ladrillos, y, por último, debe ser factible con la técnica a mano libre (12) (17).

Junto a la forma de la cáscara, el aparejo murario también debe ser diseñado. La dirección de las hiladas está directamente relacionada con el diseño de la forma, ya que determina la curvatura local practicable (12) (19). Y también está relacionada con el carácter de la técnica a mano libre, ya que cada hilada recién terminada debe tener la posición y curvatura necesarias para ser estable en sí misma y servir de base a la siguiente hilada. Asimismo, los detalles constructivos, como por ejemplo la conexión entre la cáscara y los nervios, constituyen otra condición de contorno que influirá en la definición del aparejo murario. than the modern standard. The mortar is a traditional lime mortar.

The main load bearing feature of the vault is the masonry shell, while the sandstone ribs on the inside have no structural function: due to their curvature, they cannot receive relevant normal forces. The single parts of the ribs are connected by metal bolts in longitudinal direction (this detail is common in the historical samples), and from each bolt a metal ribbon connects them to the masonry shell. Also this last aspect has a parallel in historical evidence. A similar metal connection between the ribs and the masonry shell has been observed in the vault of the Vladislav Hall (18).

The bricks are laid perpendicular to the shell surface as usual in half-stone vaults. Although the shell thickness in late Gothic vaults of the region is usually found to be equivalent to the length of one brick, in this particular case the shell was designed with the thickness of a half stone, reducing its own weight and therefore the thrust. Other possible solutions, like timbrel vaults, were not taken into account since they are not part of the repertoire of traditional construction techniques in the region.

\subsection{Methodology and form finding}

Because the vault surface must work as a shell structure, its shape is essential for the structural behavior. Therefore, the vault surface cannot be simply spanned from rib to rib, as we have already pointed out. Nevertheless, the relation between the ribs and the vault surfaces is also subject to the architectural design because has also great impact on the appearance of the vault. Moreover, as already pointed out, the surface of the vault must correspond to the possibilities to give curvature to a surface in structural masonry. And finally, the shape must be feasible in free-handed vaulting (12) (17).

Together with the shape of the shell, we had to develop a masonry texture according to the rules of regular bond pattern in structural masonry. The direction of the courses is interrelated to the design of the shape, as it determines the possible local curvature of the surfaces (12) (19). It is also related to the demand of free-handed vaulting, because every fresh course must be stable in itself in order to lay the bricks of the following course on top of it. Moreover, the detailing, in particular the connection with the ribs, constituted a boundary condition for the arrangement of the masonry texture. 
La tarea de encontrar una forma que pudiera adaptarse al sistema espacial de arcos que forman los nervios, trabajara como una cáscara autoportante, realizable en albañilería de ladrillo con un aparejo regular y que además se pudiera construir a mano libre, fue desarrollándose en un proceso iterativo usando un modelo físico, modelación por CAD, y cálculo numérico de las membranas. Fue llevado a cabo por un equipo interdisciplinario de arquitectos e ingenieros, orientándose a investigaciones previas sobre técnicas históricas de construcción de bóvedas y cáscaras estructurales de ladrillo con forma libre (Figuras 11 y 12). En el modelo físico (Figura 13) se desarrollaron diversas alternativas estudiando la interrelación entre forma y aparejo, teniendo en cuenta las condiciones de contorno y la viabilidad de los detalles [para la metodología de proyecto con modelos físicos cf. (19) (20)]. Cada propuesta fue revisada en lo que se refiere al aspecto estético, y modelada en CAD describiéndola geométricamente en términos de forma libre. Estas superficies fueron después comparadas con superficies de membranas generadas con el ordenador, aclarando hasta qué punto se ajustaban a la superficie de la cáscara. Luego, el ingeniero estructural formulaba las indicaciones sobre qué partes podrían ser problemáticas para la estabilidad de la totalidad, y a continuación la superficie era reelaborada en el modelo físico. Poco a poco pudo obtenerse una solución, una cáscara estable estructuralmente con una disposición del aparejo que cumplía con los requisitos enumerados anteriormente.

Como hemos mencionado anteriormente, en la disposición del aparejo murario es particularmente determinante el problema de que algunos nervios se situan a una considerable distancia por debajo del intradós de la cáscara de ladrillo. Esta situación es parangonable a la de otras bóvedas existentes (Figura 14), en las que son claramente visibles unos tramos cilíndricos verticales que conectan el extradós de los nervios más bajos con la superficie continua de la cascara que pasa a una considerable distancia por encima. De acuerdo con el proyecto estructural discutido aquí, tales tramos debían conectarse completamente con la cáscara, trabándose con la textura muraria de ésta. Además, para definir el aparejo murario se tuvieron en cuenta las zonas y direcciones de concentración de esfuerzos en la cáscara, así como la necesidad de duplicar el espesor de la cáscara en algunas zonas por motivos de adecuación a la figura de equilibrio.

Antes de comenzar la obra de la bóveda definitiva se construyó un prototipo corres-
The task of finding a surface that could somehow adapt to the spatial system of curves, would be stable working as a shell structure, feasible in masonry with a regular bond pattern and could even be built without formwork, was carried out in an iterative process using a physical model, CAD modeling and the numerical generation of membrane surfaces. This was done in an interdisciplinary collaboration involving architects and engineers, resorting to previous research on historical vault construction as well as on free form masonry shell structures (12) (17) (19). On the physical model (Figure 13), shapes could be developed studying the interrelation between shape and masonry apparatus as pointed out, also taking in account the complex boundary conditions given by the rib system and the detailing (for the methodology of designing on physical models cf. (19) (20)). Every trial was revised regarding the aesthetic quality, and then re-modeled in CAD according to the principles of the geometrical description (in terms of free form surfaces) that were formulated on the physical model. The surfaces created in this manner were then compared with membrane surfaces generated on the computer, clarifying the extent to which these would fit to the shell surface. On this basis, the structural engineer could formulate indications regarding those portions that would be problematic for the stability of the shell. Consequently, the surface was re-worked on the physical model. Step-by-step we were able to find a solution that provided a stable shell surface and a masonry pattern that meets the requirements mentioned above.

As mentioned, the masonry apparatus is also strongly determined by the detailing. In particular, this is relevant to the problem that some of the ribs run a considerable distance underneath the vault surface. Similar situations can be found in comparable existing vaults (Figure 14), where vertical cylindrical portions can be seen connecting the ribs, which remain in a rather low position with the shell surface at a considerable distance above. According to the structural project of the vault discussed here, such portions had to be thoroughly connected with the masonry shell, by integrating the masonry texture (Figure 15). Moreover, the layout of the masonry texture takes into account the concentration of forces and the necessity of providing areas where the shell has a double thickness.

For the final steps of the design process, a prototype vault was built representing one entire bay of the vault, for the purpose of calibrating the structural model of the 


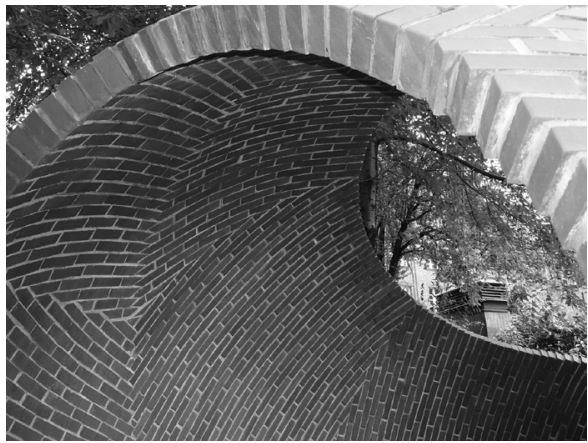

11

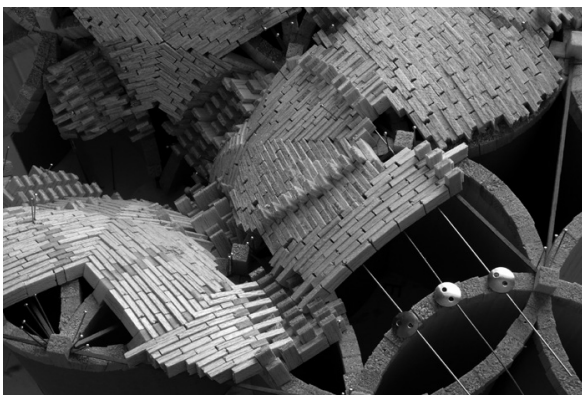

13

pondiente a un tramo para calibrar mediante una prueba de carga el complejo modelo estructural proyectado, dado que no existían experiencias modernas similares en las que poder basarse. El prototipo también debía servir para tantear el proceso constructivo, particularmente probar la ejecución de la albanilería a mano libre, altamente compleja en lo que se refiere a la geometría de la superficie y al sistema de disposición de las hiladas de ladrillo. Además haría posible familiarizarse con el uso de los materiales de construcción tradicionales, prácticamente fuera de uso en nuestros días.

Ya la construcción del prototipo se fue revelando como una tarea apasionante. Tratándose para los albañiles, aunque con experiencia en construcción de bóvedas, de una tarea completamente nueva, el proceso tuvo que ser seguido muy de cerca por los proyectistas. El modelo físico se utilizó como herramienta de trasmisión de información entre proyectistas y albañiles. Ésta resultó ser la forma más coherente y directa, dada la complejidad espacial de una superficie muraria que no se puede representar en dibujos planimétricos. El control de la forma se realizó colocando algunas cimbras-guía, cuya forma se cortó directamente según las secciones obtenidas de la superficie CAD e imprimidas a escala 1:1, y mediante guías flexibles que controlaban la continuidad de la superficie. Al no tener que transmitir la geometría recurriendo a medidas, es decir, codificando algo que luego hay que descodificar para aplicarlo, el proceso es mucho más directo y se excluye la posibilidad de errores. Así,

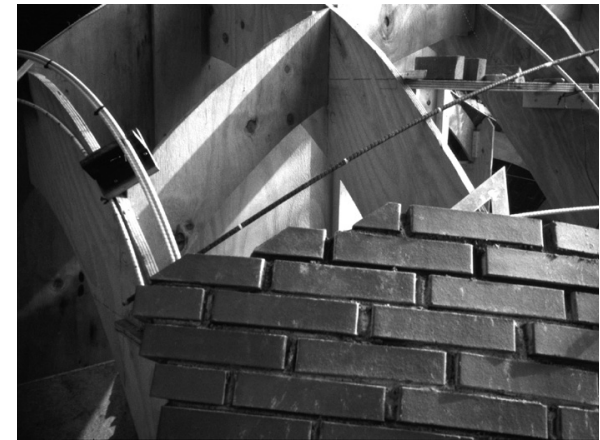

12

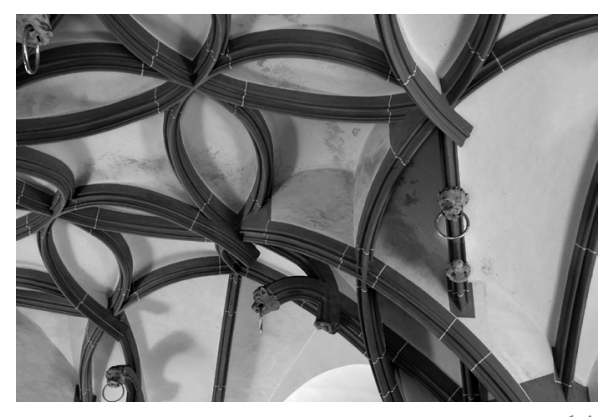

complex structure through load testing. This prototype also served to help us assess the building process, especially the execution of the masonry structure, which is highly complex regarding the geometry of its surface and the masonry apparatus. Further, the use of the traditional building materials no longer common in today's construction could be tested.

The realization of this prototype was as demanding as fascinating. Since the task was novel for the masons (although experienced in vault construction), the designers had to issue detailed instructions and offer a close supervision of the works. Here, the physical model also assisted in the communication between workmen and designers. The model turned out to be the most coherent and direct way to explain the complex masonry construction, as it cannot be represented by the usual planimetric drawings. The form control was accomplished by providing a number of centering arches, which were cut from plywood according to the curves obtained from the CAD model, in combination with flexible rulers in order to control the continuity of the shell surface. As with this procedure, the geometry was imposed without measuring (which would have meant codifying and again de-codifying information); it was the most direct and error-proof method. Altogether, we found that in the construction process, the designed solution was very practical and feasible without problems in spite of its complexity, as soon as a good communication with the workers was established.
11. En la construcción experimental de una estructura de cáscara (D. Wendland, W. Kurtz, F. Schneider y estudiantes de la Universidad Técnica de Dresde, 2006) se examinaron las posibilidades de realización de formas libres en ladrillo sin armadura. (Fotografía de los autores).

11. In an experimental shell structure in unreinforced masonry (D. Wendland, W. Kurtz, F. Schneider and students of the TU Dresden, 2006) the possibilities of realizing free forms in masonry were assessed (photograph by the authors)

12. El control de la forma de la albañilería se realizó mediante arcos de cimbra cortados de tablones de madera según las secciones obtenidas del CAD, y mediante guías flexibles. (Fotografía de los autores).

12. The shape control of the curved masonry was carried out by means of centering arches cut from wooden panes according to the CAD sections, and flexible rulers (photograph by the authors).

13. Modelo físico para encontrar la forma de la cáscara, simulando la disposición del aparejo de los ladrillos y la manera de realizar el control geométrico, y debiendo cumplir las condiciones de contorno. (Fotografía de los autores).

13. Physical form finding model for the shell, simulating the masonry apparatus and the principle geometry control, upon the given boundary conditions (model and photograph by the authors).

14. Bóveda de un anexo de la iglesia de Annaberg (Alemania), donde se aprecia el conflicto entre el sistema de curvas de los nervios y la superficie de la cáscara estructural. La separación entre nervios y cáscara se resuelve conectandolos por medio de tramos verticales cilíndricos. (Fotografía de los autores).

14. The vault in the annex room of the church of Annaberg shows the conflicts between the spatial system of curves constituted by the ribs, and the surface of the load bearing masonry shell. Large distances between the ribs and the shells are connected by vertical cylindrical portions (photograph by the authors) 
15. Tramo de prueba durante la construcción: el aparejo elegido resuelve el problema de la distancia existente entre la cáscara y los extradoses de los nervios más bajos. (Fotografía de los autores).

15. Prototype vault during construction: The connection of the shell with the ribs located on different levels is accomplished by the arrangement of the masonry pattern (photograph by the authors)

16. Bóveda durante la construcción. Se observan las guías flexibles empleadas para controlar la forma. (Fotografía de los autores).

16. Vault during construction: note the use of the flexible rulers for the form control (photograph by the authors).

17. Bóveda durante la construcción: se aprecian la superficie de la cáscara, los tramos verticales que la conectan con los nervios, el aparejo, y un arco de cimbra en el centro, el único soporte necesario para poner los ladrillos. (Fotografía de los autores).

17. Vault during construction: The shell surface, the vertical portions connecting with the lower ribs, and a centering arch seen from below, showing the masonry apparatus. No further support was needed for brick-laying (photograph by the authors).

18. Bóveda durante la construcción. (Fotografía de los autores).

18. Vault during construction (photograph by the authors).

19. Prototipo de la bóveda dispuesto a ser sometido a la prueba de carga (Fotografía de los autores).

19. The prototype bay prepared for the load testing (photograph by the authors).

20. Vista del extradós del prototipo: se observa que, aunque en el desarrollo se han seguido principalmente criterios tecnológicos, el resultado coincide extraordinariamente con lo que vemos en ejemplos históricos. (Fotografía de los autores).

20. Extrados of the prototype vault. Although the design process was essentially guided by technological criteria, the result is surprisingly coincident with the evidence on comparable historical vaults (photograph by the authors). la solución propuesta se demostró práctica y factible, sin mayores problemas en cuanto se estableció una buena comunicación con los albañiles (Figuras 15, 16, 17, 18).

Así, en la realización del prototipo, la factibilidad del diseño pudo verificarse con éxito en todos los aspectos sometidos a prueba: el ensamblaje del sistema de nervios, el diseño de la cáscara, la viabilidad del aparejo en general y en los detalles, y la técnica a mano libre. La prueba de carga resultó un éxito, excediendo incluso las espectativas (Figuras 19, 20).

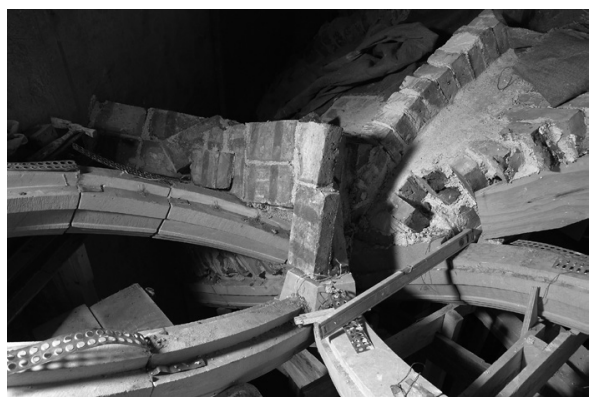
15
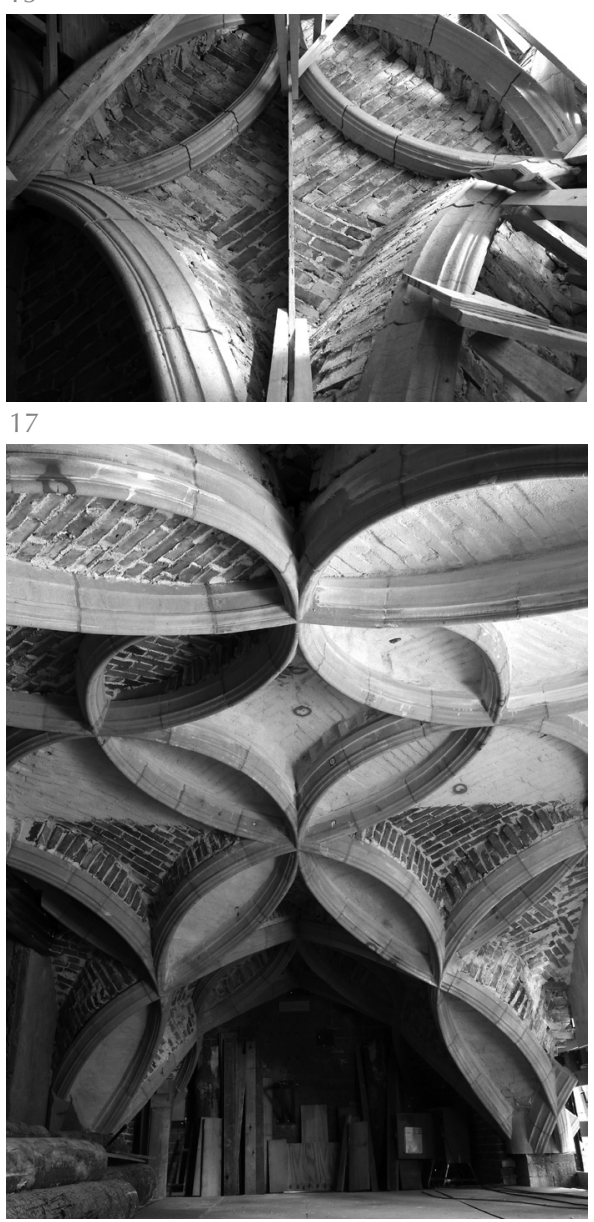

19
Hence, in the execution of the prototype bay, the design could be successfully verified regarding the assembly of the rib system, the design of the masonry shell, the feasibility of its apparatus and details, and free-handed vaulting. The load test was a great success since the response of the structure exceeded the expectations (Figures 19, 20).
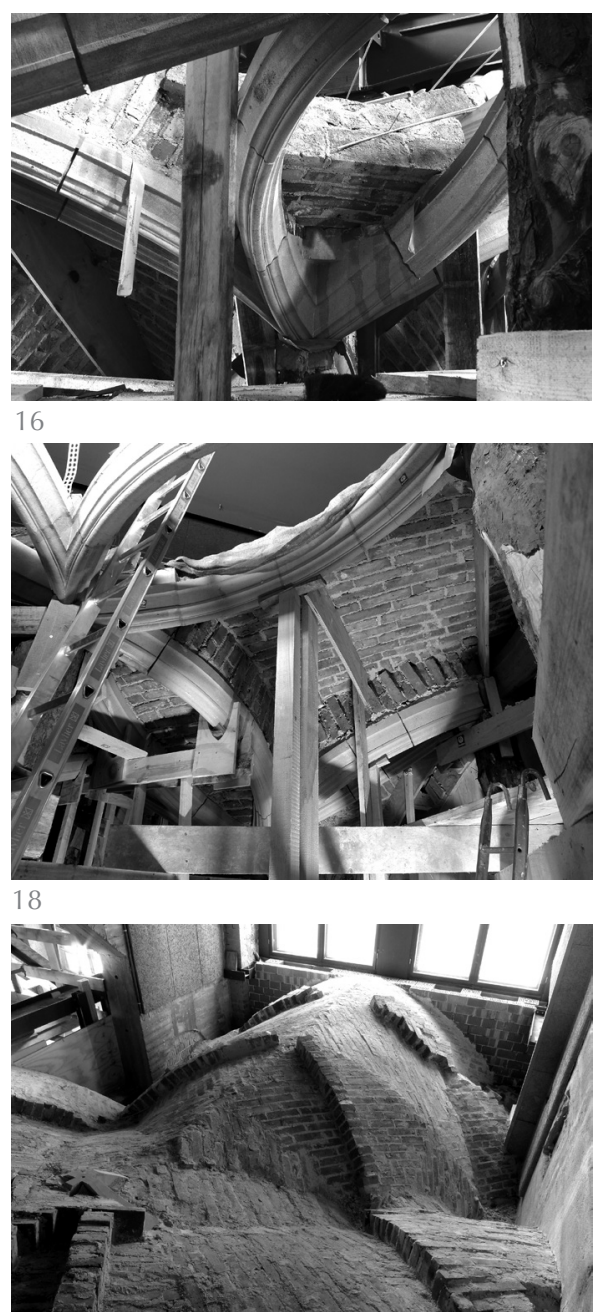

20 


\section{CONCLUSIONES}

El hecho de que, en el caso que nos ocupa, no se tratase de la verificación del estado estructural de una bóveda existente y su consiguiente restauración, sino de proyectar y construir una bóveda histórica nueva (Figuras 21, 22), es un reto particular. La decisión de desarrollar una solución tecnológica afrontando las exigencias de una estructura de nueva construcción y evitando hacer una simple compilación de elementos copiados de ejemplos históricos, lleva a un resultado que se manifiesta mucho más compatible con lo que vemos en las construcciones originales. Así, este proyecto contribuye en gran medida a incrementar nuestros conocimientos sobre construcción histórica.

Además, la reproducción de tan extraordinario edificio, reuniendo proceso de diseño y ejecución técnica, puede ayudar a recuperar las cualidades inmateriales de nuestro legado cultural, en términos de conocimiento técnico y cultura constructiva, que han ido perdiéndose a traves de los siglos.

Por último, estamos ante un ejemplo de diseño y construcción de una forma libre de ladrillo sin armadura. Como las formas libres son objeto de gran interés en la arquitectura contemporanea, un proyecto de este tipo pone de manifiesto la actualidad que tiene el estudio de estructuras históricas.

\section{CONCLUSIONS}

It has been a particular challenge to actually design and build a new "historical" vault (Figures 21,22) rather than verifying and restoring an existing historical vault. By not proceeding by simply compiling historical examples, but instead developing a technological solution to meet the requirements of a new structure, we devised a design process that turns out to be very much compatible with what can be observed on the original historical examples. For this reason, this project greatly contributes to our knowledge about historical constructions.

Moreover, the reproduction of such an outstanding building, reenacting both the historical design process and the technical execution, may help recover the immaterial qualities of architectural heritage, in terms of technical knowledge and the building culture, which has been lost through the centuries.

Finally, this project also yielded an example of the design of a free form shell structure in unreinforced masonry. As free forms in architecture are of great interest in new architecture, this may demonstrate the actuality of historical structures.
21. Construcción de la bóveda definitiva. (Fotografía de los autores).

21. Construction of the defini tive vault (photograph by the authors).

22. Vista parcial de la bóveda definitiva durante la construcción. (Fotografía de los autores).

22. Partial view of the definitive vault during construction (photograph by the authors)
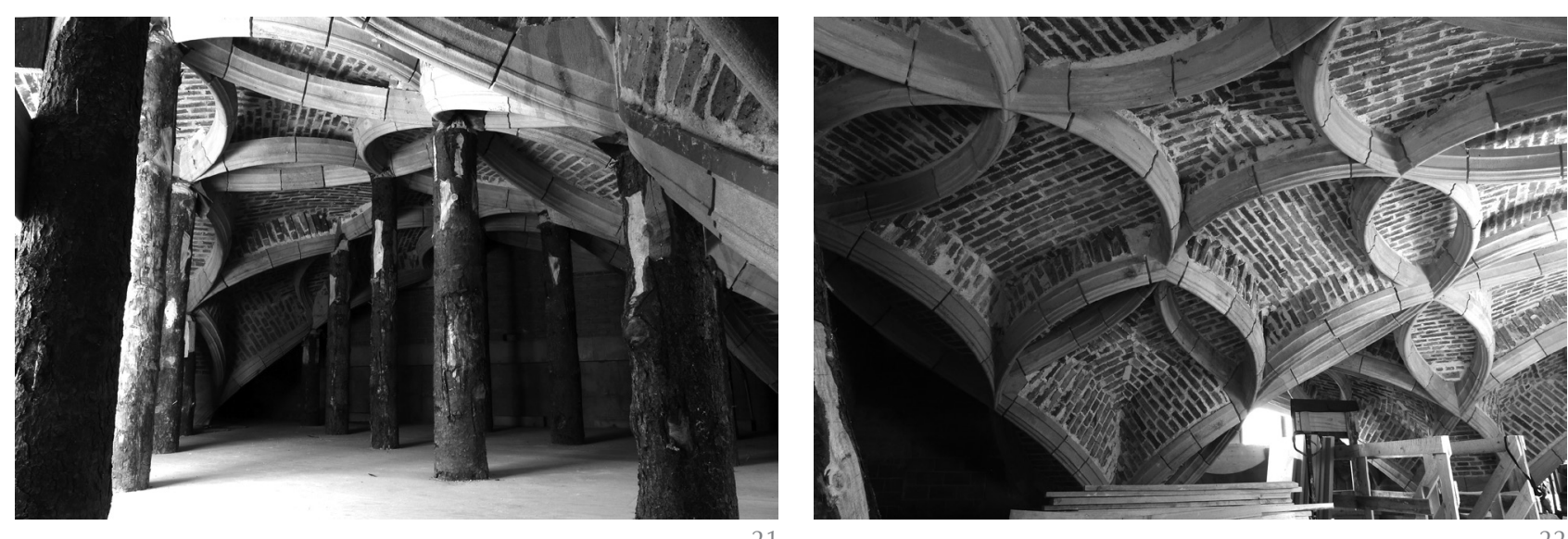

\section{AGRADECIMIENTOS}

La investigación sobre bóvedas tardogóticas ha sido llevada a cabo dentro del proyecto ERC Starting Grant "Design Principles in Late-Gothic Vault Construction - A New Approach Based on Surveys, Reverse Geometric Engineering and Reinterpretation of the Sources" financiado por el Consejo Europeo de Investigación (European Union's Seventh Framework Programme (FP7/20072013) / ERC grant agreement $n^{\circ} 284373$ ).

\section{ACKNOWLEDGEMENTS}

The investigations of late Gothic vaults are carried out with the ERC Starting Grant "Design Principles in Late-Gothic Vault Construction - A New Approach Based on Surveys, Reverse Geometric Engineering and Reinterpretation of the Sources", which is receiving funding from the European Research Council under the European Union's Seventh Framework Programme (FP7/2007-2013) / ERC grant agreement $n^{\circ} 284373$. 
La concepción, desarrollo y supervisión de la realización de la cáscara de ladrillo de la bóveda han sido llevados a cabo por los autores, en colaboración con J.-U. Anwand y J. Fleischer (estudio de arquitectura J.-U. Anwand Architekten) y M. Kröning (estudio de ingeniería KUS Ingenieurbüro für Baustatik und Tragwerksplanung). En el momento de redacción de este artículo la bóveda todavía se encuentra en proceso de construcción. La fecha prevista para su conclusión es julio de 2013.

La reconstrucción de la capilla del Palacio de Dresde es una obra pública emprendida por el Staatsbetrieb Sächsisches Immobilien-und Baumanagement (SIB). Autor del proyecto arquitectónico es el estudio J.-U. Anwand Architekten; proyecto estructural de KUS Ingenieurbüro für Baustatik und Tragwerksplanung; asesoramiento científico por S. Bürger y D. Wendland; estudios preliminares arqueológicos y de documentación por H.-C. Walther; construcción por la empresa Dressler Bau $\mathrm{GmbH}$, bajo dirección de T. Bauer. Prueba de carga proyectada por KUS y realizada por M. Curbach, Otto-Mohr-Laboratorium de la Universidad de Dresden. La hipótesis de la figuración original de la bóveda es de S. Bürger y J.-U. Anwand. Deseamos expresar nuestro agradecimiento a L. Coulin (director del SIB), H. Krause (director del grupo encargado del proyecto) y S. Gierth (SIB), así como a S. Rau y a M. Fleischer (Dressler Bau $\mathrm{GmbH}$ ).
The concept, development and supervision of the masonry shell construction for the vault have been carried out by the authors, in collaboration with J.-U. Anwand and J. Fleischer (J.-U. Anwand Architekten, Dresden) and M. Kröning (KUS Ingenieurbüro für Baustatik und Tragwerksplanung, Dresden). During the preparation of this article the building is under construction, with completion of the vault scheduled for July 2013.

The reconstruction of the chapel in the Dresden Castle is a public construction project performed by Staatsbetrieb Sächsisches Immobilienund Baumanagement (SIB), Dresden (Germany). The architectural design is by J.-U. Anwand Architekten, structural design by KUS Ingenieurbüro für Baustatik und Tragwerksplanung, scientific consultancy S. Bürger and D. Wendland, archaeological and documentary studies by Mr. Walther (all Dresden), construction works Dressler Bau GmbH under direction of T. Bauer. Load testing was carried out by Prof. Dr.Ing. M. Curbach, Otto-Mohr-Laboratorium of TU Dresden, based on experiment design by KUS. The hypothesis on the original figuration of the vault is by S. Bürger and J.$U$. Anwand. We wish to express gratitude to L. Coulin (head of SIB Dresden I), H. Krause (group leader in charge of the project) and S. Gierth (SIB Dresden), and S. Rau, M. Fleischer, M. Kramer and ). Freitag (Dressler Bau $\mathrm{GmbH}$ ).

We wish to thank Jessica Buskirk for revising the English text.

\section{REFERENCIAS / REFERENCES}

(1) Anwand, J-U. (2010). Residenzschloss Dresden - Schlosskapelle - Das Gewölbe (unpublished report) Dresden, SIB.

(2) Anwand, J-U., ed. (2013) Rekonstruktion des spätgotischen Schlingrippengewölbes in der Dresdner Schlosskapelle. Altenburg. Kamprad (forthcoming).

(3) Anwand, J.-U., J. Fleischer, M. Kröning, U. Schröter and D. Wendland (2012). A Masonry Structure With Complex Geometry: Reconstructing the Late Gothic Vault in the Palace Chapel at Dresden Using Traditional Building Technique. Proceedings $8^{\text {th }}$ International Conference on Structural Analysis of Historical Constructions, 2: 1339-1346. Wroclaw.

(4) Kröning, M. (2010). Erläuterungen zur Tragwerksplanung (unpublished report). Dresden, SIB

(5) Magirius, H. (2009). Die evangelische Schlosskapelle zu Dresden aus kunstgeschichtlicher Sicht. Altenburg. Kamprad.

(6) Löffler, F. (1966). Das alte Dresden: Geschichte seiner Bauten. Leipzig. Seemann / Frankfurt. Weidlich.

(7) Nußbaum, N. and S. Lepsky. (1999). Das gotische Gewölbe: Eine Geschichte seiner Form und Konstruktion. Darmstadt. Wissenschaftliche Buchgesellschaft.

(8) Muk, J. (1990). Die Gewölbe des Benedikt Ried. In Geschichte des Konstruierens IV, Wölbkonstruktionen der Gotik 1: 193-205. Stuttgart / Tübingen. SFB 230.

(9) Willis, R. (1842). On the construction of the vaults in the middle-ages. In Transactions of the Royal Institute of British Architects, 1: 1-69.

(10) Müller, W. (2002). Steinmetzgeometrie zwischen Spätgotik und Barock. Petersberg. Imhof. 
(11) Müller, W. and N. Quien (2005). Virtuelle Steinmetzkunst der österreichischen und böhmisch-sächsischen Spätgotik: Die Gewölbeentwürfe des Codex Miniatus 3 der Österreichischen Nationalbibliothek in Wien. Petersberg. Imhof.

(12) Wendland, D. (2008). Lassaulx und der Gewölbebau mit selbsttragenden Mauerschichten. Neumittelalterliche Architektur um 1825-1848. Petersberg. Michael Imhof.

(13) Wendland, D. and M.J. Ventas Sierra (2010). Zum Bau figurierter Gewölbe - eine Anleitung im Werkmeisterbuch des Rodrigo Gil de Hontañón. In Werkmeister der Spätgotik: Personen, Amt und Image, edited by S. Bürger, B. Klein and K. Schröck, 244-269. Darmstadt. Wissenschaftliche Buchgesellschaft.

(14) Nußbaum, N. (2012). Planen ohne Wörter - zur Kommunikation in gotischen Bauhütten. In Bautechnik im Historismus: Von den technischen Theorien über die Gotik bis zu den großen Baustellen, ed. by U. Hassler, C. Rauhut and S. Huerta, 281-291. München. Hirmer.

(15) Wendland D. (2012). Arches and Spirals: The Geometrical Concept of the Curvilinear Rib Vault in the Albrechtsburg at Meissen and Some Considerations on the Construction of Late-Gothic Vaults with Double-Curved Ribs. Nuts and Bolts of Construction History: Culture, Technology and Society, 1:351-357. Paris. Picard.

(16) Cologne, Historisches Archiv, Best. 7020 Nr. 276 (Jacob Facht von Andernach).

(17) Wendland, D. (2007). Traditional vault construction without formwork: Masonry pattern and vault shape in the historical technical literature and in experimental studies. International Journal of Architectural Heritage, 1(4), 311-365.

(18) Chotebor P. (forthcoming) Das Gewölbe des Wladislawsaals der Prager Burg und seine Details. Traces of Making, ed. by K. Schröck and D. Wendland. Petersberg: Imhof.

(19) Wendland D. (2009). Experimental Construction of a Free-Form Shell Structure in Masonry. International Journal of Space Structures, 24(1): 1-11.

(20) Tomlow J. (1989). Das Modell - Antoni Gaudís Hängemodell und seine Rekonstruktion (IL 34). Stuttgart. IL/Krämer. 